УДК 338.2

\title{
КОНКУРЕНТНЫЕ ПРЕИМУЩЕСТВА НАЦИОНАЛЬНОЙ ЭКОНОМИКИ
}

Смирнов Алексей Юрьевич

Д.э.н., доценТ

Неуступова Алина Серафимовна к.э.Н, доцент

Санкт-Петербургский государственный морской технический университет

Аннотация: Авторы рассматривают, как влияет на уровень конкурентоспособности национальной экономики Российской Федерации ее обеспеченность трудовыми, финансовыми и информационными ресурсами. В статье делается вывод, что уровень развития информационных технологий будет определять конкурентный потенциал народного хозяйства в стратегическом периоде времени.

Ключевые слова: конкурентоспособность, рабочая сила, информационные ресурсы, финансовый потенциал.

\section{COMPETITIVE ADVANTAGES OF THE NATIONAL ECONOMY}

\section{Smirnov Aleksey Yur'yevich Neustupova Alina Serafimovna}

\begin{abstract}
The authors consider how the level of competitiveness of the national economy of the Russian Federation is affected by its availability of labor, financial and information resources. The article concludes that the level of development of information technologies will determine the competitive potential of the national economy in the strategic period of time.

Key words: competitiveness, labor force, information resources, financial potential

Экономическая обстановка в мире начиная со второй половины прошлого века характеризуется постоянным ростом объемов производства и повышением жизненного уровня населения, особенно в развитых странах.
\end{abstract}


Мировой раздел рынков между крупнейшими монополиями завершен, что препятствует выходу на рынок новых конкурентоспособных производителей продукции. Однако при этом конкурентная борьба между отдельными ТНК продолжается, приобретая все более изощренные формы, на основе использования всех современных достижений в сфере психологии и социологии. Причина этого в том, что по большинству товарных позиций спрос на мировом рынке уступает предложению. Рынок является насыщенным, что способствует активизации конкурентной борьбы. В тоже время спрос на иностранные инвестиции существенно уступает предложению, что приводит к борьбе за инвестиции между отдельными странами. Особое значение борьба за привлечение иностранных инвестиций приобретает для развивающихся стран, которые в силу нехватки внутренних сбережений, не в состоянии отказаться от внешних источников финансирования, если хотят добиться долгосрочного экономического роста. Возникает вопрос, каковы перспективы России при таком раскладе сил?

Существует мнение, что Россия обладает конкурентным преимуществом в силу наличия дешевой и квалифицированной рабочей силы. Данный тезис представляется ошибочным.

Во-первых, сам по себе уровень образования есть простой статистический показатель, ничего не говорящий о качестве образования. А качество образования в России в среднем не велико. И проблема здесь заключается не в уровне педагогических кадров, который достаточно высок, а в отношении самих учащихся. Престиж образования в России низок. Можно вообще не иметь образования, а зарабатывать денег в десятки раз больше, чем профессор в университете. Кроме того, есть определенные недостатки и в самой системе. Так, школы зачастую вынуждены держать до 9 класса тех, кто совершенно не хочет учиться, кто не заинтересован в получении знаний. И здесь никакое изменение школьных программ не даст результатов. Да и в вуз многие поступают для того, чтобы получить не знания, а диплом о высшем образовании. Не претендуя на репрезентативность, отметим, что по собственным наблюдениям авторов количество таких студентов превышает $50 \%$ на дневном отделении, не говоря уже о вечернем и заочном образовании, где указанный показатель еще выше.

Кроме того, негативное влияние на квалификацию рабочей силы оказывают социальные процессы, происходящие в современном обществе. Распространение алкоголизма и наркомании существенно снижают 
конкурентоспособность трудовых ресурсов России.

Во-вторых, дешевизна рабочей силы компенсируется низкой производительностью труда в России. В России работник мало получает, но и производит он меньше, чем на Западе. В результате роста заработной платы опережающими темпами по отношению к производительности труда, а такая тенденция прослеживается в экономике России, начиная с середины 80-х годов, конкурентоспособность экономики будет уменьшаться.

Огромной проблемой для российской экономики является уровень подготовки управленческого звена, которая остается слабой. Несмотря на достижения современного менеджмента, руководители предприятий часто относятся к подчиненным, как к одушевленным орудиям труда, используя в качестве мотиватора только заработную плату. В результате, если западные технологии ориентированы на то, чтобы получить от человека максимум возможного, использовать все его способности на благо организации, то в России творческий потенциал работника используется ограниченно.

Кроме того, при существующей социально-экономической обстановке в России наиболее квалифицированные работники просто покидают страну, используя свои способности на благо экономики западных стран. Возникает парадокс - высокая квалификация рабочей силы в России оказывается выгодной для развитых стран Запада, прежде всего США.

По нашему мнению, нехватка финансовых ресурсов является одно из серьезнейших проблем экономики страны. Эта проблема вызвана двумя основными причинами: резким снижением уровня внутренних инвестиций и отсутствие притока значительных средств из-за рубежа. Важным негативным фактором является низкая капитализация российского рынка. Акции российских предприятий стоят дешевле, чем акции зарубежных компаний, имеющих аналогичные показатели прибыли и объема продаж. Причина этого заключаются как в общей неразвитости фондового рынка в России, так и в отсутствие значительных выплат по акциям. В период массовой приватизации основным свойством акции стало предоставляемое владельцу право на участие в управлении, то есть доля экономической власти. В результате дивиденды, которые реально выплачиваются по акциям весьма невелики. Тем самым акция утрачивает свои экономические черты.

Отметим, что в современном мире информационные ресурсы приобретают основное значение. Эффективное развитие предприятия невозможно без хорошо отлаженной информационной системы. Следует 
отметить, что развитие информационных технологий в России идет активными темпами, значительная часть российских предприятий уже имеет доступ к Интернету, а также пользуется разнообразными программами, облегчающими повседневную деятельность: бухгалтерскими, складскими, автоматизированного документооборота и т.д. Однако проблема здесь заключается в том, что по уровню развитию информационных технологий даже Европа существенно отстала от США. По мнению исследователей, в Европе не существует «новой экономики», по крайней мере, в американском смысле. Если сравнить США с другими промышленными державами почти по любым показателям, характеризующим степень развития «Новой экономики» - числу персональных компьютеров, уровню подключения к Интернету, рисковому предпринимательству, - то можно сделать вывод, что США существенно опережают всех основных конкурентов. В течение большей части 1990-х годов США опережали Европу в объеме инвестиций в информационные технологии в пропорции почти 2 к 1, но этот разрыв, как ожидают, будет преодолен. Наблюдаемое снижение темпов экономического роста в США может существенно способствовать преодолению существующего разрыва.

При этом, по мнению директора Института проблем глобализации М. Делягина, специфика информационных технологий состоит в том, что сам факт их применения делает для применяющей стороны принципиально невозможной всякую серьезную конкуренцию с разработчиком технологий. Это своего рода плата за допуск к более высокой эффективности, обеспечиваемой этими технологиями. Помимо обеспечения глобальной информационной прозрачности, наиболее важной чертой информационных технологий является возможность глубокой и относительно произвольной перестройки массового сознания. Дело в том, что, в отличие от традиционных технологий, продуктом которых является товар, продуктом информационных технологий является определенное состояние человеческого сознания, в том числе массового. Более того, значительная часть информационных технологий изначально предназначена именно для такой перестройки сознания, имея ее в качестве главной цели воздействия.

Отсюда можно сделать вывод, что без преодоления отставания в сфере не только использования, но и производства информационных технологий, Россия обречена на существование в качестве одной из стран периферии. 


\section{Список литературы}

1. Гельвановский М.И. Национальная стратегия конкурентоспособности как основа промышленной политики России // Россия и совр. мир. - 2006. N 3. - C.118-128.

2. Киселева И.А. Конкурентоспособность предприятия в условиях глобализации общества: влияние корпоративной культуры / И.А. Киселева, Н.Е.Симонович // Нац. интересы: приоритеты и безопасность. - 2014. - N 11. C.39-44.

3. Клековкин Л.И. Системный подход к пониманию конкурентоспособности как фактор устойчивого развития экономики // Нац. интересы: приоритеты и безопасность. - 2010. - N 17. - С.32-38.

4. Кузьмин Д. Национальная конкурентоспособность, глобальное равновесие и мировая валютная система // Мировая экономика и междунар. отношения. - 2011. - N 3. - С.17-23.

5. Кулаков В.О глобальной конкурентоспособности России / В. Кулаков, 3. Алиев // Власть. - 2010. - N 5. - С.60-63. 